\title{
Alina Grynia \\ FUNKCJONOWANIE I FINANSOWANIE EUROPEJSKIEJ POLITYKI RYNKU PRACY W CZASACH ŚWIATOWEGO KRYZYSU GOSPODARCZEGO
}

\section{Wprowadzenie}

Współczesny kryzys gospodarczy objął praktycznie wszystkie kraje. Wzrost zatrudnienia w ostatniej dekadzie w dużej mierze miał charakter koniunkturalny, więc i spadek zatrudnienia w czasach spowolnienia miał znaczący wymiar. Pogorszenie sytuacji na rynku pracy zazwyczaj prowadzi do zwiększenia zadań polityki rynku pracy. Polityka rynku pracy jest traktowana jako element interwencji państwa w mechanizmy rynkowe, wynikającej z negatywnych zjawisk pojawiających się na rynku pracy, inaczej mówiąc, wynika z zawodności tego mechanizmu. ${ }^{1}$ Polityka ta, realizowana w różnych krajach o odmiennych systemach gospodarczych i społecznych, może znacznie się różnić. Generalnie, im szerszy jest zakres ingerencji państwa na rynku pracy, tym wyższe są koszty realizacji i z założenia wyższa efektywność zastosowania.

Najogólniej rzecz ujmując, w ramach polityki rynku pracy można wyróżnić aktywną politykę państwa (active labour market policy - ALMP) oraz pasywną (passive labour market policy - PLMP). Pierwsza ma zapewnić stabilność i długofalowy rozwój, przy równoczesnej likwidacji nierówności społecznych. W przypadku ALMP stosuje się wiele programów, które są skierowane przede wszystkim do osób bezrobotnych. Pasywna polityka rynku pracy zapewnia natomiast ochronę socjalną bezrobotnych i stanowi materialne zabezpieczenie osób, które utraciły pracę i ze względu na niski popyt lub brak odpowiednich kwalifikacji nie mogą jej znaleźć. W tym celu państwa wykorzystują zasiłki dla bezrobotnych, świadczenia z zakresu pomocy społecznej i inne formy pomocy socjalnej, zapewniające środki na utrzymanie osobom bezrobotnym.

${ }_{1}$ Z. Wiśniewski, Kierunki i skutki regulacji rynku pracy w krajach Unii Europejskiej, Wydawnictwo UMK, Toruń 1999, s. 11-12. 
W opracowaniu prezentuję podstawowe instrumenty pasywnej i aktywnej polityki rynku pracy, specyfikę ich stosowania i finansowania w czasach kryzysu gospodarczego oraz skuteczność stosowania aktywizujących narzędzi.

\section{Sytuacja na europejskim rynku pracy}

W 2008 roku w całym regionie miało miejsce znaczące spowolnienie gospodarcze, którego skutki w mniejszym lub większym stopniu odczuły wszystkie kraje. Doprowadziło ono do licznych bankructw firm oraz masowych zwolnień pracowników. Miało to istotne znaczenie dla polityki rynku pracy, ponieważ oznaczało duży wzrost bezrobotnych w różnym wieku, z różnym wykształceniem i o różnych kwalifikacjach.

Jak wynika z raportu Zatrudnienie w Europie 2009, od chwili wybuchu kryzysu w UE zlikwidowano 4 mln miejsc pracy, a w całej Europie w tym czasie bez pracy znalazło się nieco ponad $20 \mathrm{mln}$ osób. Oznacza to, iż podczas trwającego kryzysu ich liczba wzrosła o $21 \%$. W tymże roku liczba bezrobotnych w skali światowej wzrosła do $212 \mathrm{mln} .^{2}$

Tabela 1. Podstawowe wskaźniki rynku pracy UE-27 w latach 2005-2010 (w \%)

\begin{tabular}{|l|r|r|r|r|r|r|}
\hline \multicolumn{1}{|c|}{ Wskaźnik } & 2005 & 2006 & 2007 & 2008 & 2009 & 2010 \\
\hline Stopa bezrobocia ogółem & 9,0 & 8,3 & 7,2 & 7,1 & 9,0 & 9,7 \\
\hline Bezrobocie dla wieku 15-24 & 18,6 & 17,3 & 15,5 & 15,5 & 19,8 & 20,8 \\
\hline \multicolumn{1}{|c|}{ 25-54-64 } & 7,9 & 7,2 & 6,2 & 6,1 & 7,9 & 8,6 \\
\hline Bezrobocie mężczyzn & 6,4 & 6,2 & 5,5 & 5,1 & 6,3 & 6,9 \\
\hline Bezrobocie kobiet & 8,4 & 7,6 & 6,6 & 6,7 & 9,1 & 9,7 \\
\hline Długookresowo bezrobotni & 9,8 & 9,0 & 7,9 & 7,6 & 9,0 & 9,6 \\
\hline Zatrudnienie ogółem & 4,1 & 3,7 & 3,1 & 2,6 & 3,0 & 3,9 \\
\hline Zatrudnienie dla wieku 15-24 & 63,5 & 64,5 & 65,4 & 65,9 & 64,6 & 64,2 \\
\hline Zatrudnienie kobiet & 36,1 & 36,6 & 37,4 & 37,5 & 35,1 & 34,1 \\
\hline Zatrudnienie mężczyzn & 56,3 & 57,3 & 58,3 & 59,1 & 58,6 & 58,2 \\
\hline Zatrudnienie 50+ & 70,8 & 71,6 & 72,5 & 72.8 & 70,7 & 70,1 \\
\hline Niepełne zatrudnienie & 42,3 & 43,5 & 44,6 & 45,6 & 46,0 & 46,3 \\
\hline
\end{tabular}

Źródło: Eurostat, http://appsso.eurostat.ec.europa.eu/nui/show.do?dataset=lfsa_ergan\&lang=en (dostęp 02.10.2011).

2 Employment in Europe report 2009, http://ec.europa.eu/social/main.jsp?catId=119\&langId=en (dostęp 10.05.2010). 
W tabeli 1 przedstawiono zmianę podstawowych wskaźników charakteryzujących europejski rynek pracy w ostatnich sześciu latach. Z zamieszonych w niej danych wynika, że w 2008 roku w całym ugrupowaniu odnotowano najwyższy poziom zatrudnienia - około 66\%, który w następnych dwóch latach spadał i w 2010 roku zatrzymał się na poziomie nieco powyżej $64 \%$. Można zatem mówić, iż w czasie kryzysu wystąpił spadek zatrudnienia o blisko 2 pkt. proc. Podobne tendencje można zaobserwować w przypadku zmian wskaźnika zatrudnienia wśród kobiet. W okresie 2005-2009 analizowany wskaźnik systematycznie wzrastał z 56,3\% do $58,6 \%$ (o 2,3 pkt. proc.). W ostatnim roku analizowanego okresu wskaźnik ten zmalał, ale bardzo niewiele - o 0,4 pkt. proc.

Poziom zatrudnienia mężczyzn w latach 2005-2008 był przeciętnie na poziomie o blisko 14 pkt. proc. wyższy niż wskaźnik zatrudnienia kobiet. W 2009 roku natomiast miał miejsce spadek tego wskaźnika o ponad 2 pkt. proc., co zmniejszyło różnicę w poziomie zatrudnienia kobiet i mężczyzn do około 12 pkt. proc. z utrzymaniem się przewagi tego ostatniego.

Tradycyjnie niski wskaźnik zatrudnienia miał miejsce w przypadku młodych ludzi (do 25 lat) - w okresie sprzed kryzysu odznaczał się on tendencją wzrostową i w 2008 roku osiągnął poziom 37,5\%. W następnych dwóch latach wystąpił spadek odsetka pracującej młodzieży o ponad 3 pkt. proc. i ukształtował się na najniższym w ostatniej dekadzie poziomie - 34,1\%. Jedynym wskaźnikiem charakteryzującym poziom zatrudnienia w UE-27, który odznaczał się tendencją wzrostową w całym badanym okresie, był poziom zatrudnienia w grupie starszych osób (50+). W latach 2008-2009 wysokość omawianego wskaźnika sięgała 46\%, tym niemniej był to poziom znacznie niższy niż w przypadku zatrudnienia kobiet, lecz wyższy niż dla młodych ludzi.

Następnym miernikiem, który pozwoli określić sytuację na europejskim rynku pracy, będzie poziom bezrobocia. W całej Unii Europejskiej można zaobserwować spadek poziomu bezrobocia w latach 2005-2008, gdy stopa bezrobocia zmalała z 9\% do 7,1\%. Co prawda w roku 2008 stopa bezrobocia obniżyła się zaledwie o 0,1 pkt. proc., czyli można mówić, iż pozostała na tym samym poziomie co w 2007 roku. Kryzys natomiast zakłócił tę optymistyczną tendencję i w 2009 roku miał miejsce gwałtowny wzrost stopy bezrobocia do poziomu 9\% (o blisko 2 pkt. proc.), zaś w 2010 roku o kolejne 0,7 pkt. proc. W 2010 roku poziom bezrobocia osiągnął wysokość $9,7 \%$ i był to najwyższy poziom bezrobocia dla ostatnich dziesięciu lat. W 11 krajach członkowskich w 2010 roku poziom bezrobocia był wyższy niż dla całej Unii, a mianowicie w Hiszpanii, Litwie, Łotwie, Estonii, Słowacji, Irlandii, Grecji, Portugalii, Bułgarii, Francji i na Węgrzech (tabela 2). 
Tabela 2. Poziom bezrobocia w krajach UE w latach 2007-2010 (w \%)

\begin{tabular}{|l|r|r|r|r||l|r|r|r|r|}
\hline \multicolumn{1}{|c|}{ Państwo } & 2007 & 2008 & 2009 & 2010 & Państwo & 2007 & 2008 & 2009 & 2010 \\
\hline Hiszpania & 8,3 & 11,3 & 18,0 & 20,1 & Finlandia & 6,9 & 6,4 & 8,2 & 8,4 \\
\hline Łotwa & 6,0 & 7,5 & 17,1 & 18,7 & Szwecja & 6,1 & 6,2 & 8,3 & 8,4 \\
\hline Litwa & 4,3 & 5,8 & 13,7 & 17,8 & Belgia & 7,5 & 7,0 & 7,9 & 8,3 \\
\hline Estonia & 4,7 & 5,5 & 13,8 & 16,9 & W. Brytania & 5,3 & 5,6 & 7,6 & 7,8 \\
\hline Słowacja & 11,1 & 9,5 & 12,0 & 14,4 & Dania & 3,8 & 3,3 & 6,0 & 7,4 \\
\hline Irlandia & 4,6 & 6,3 & 11,9 & 13,7 & Czechy & 5,3 & 4,4 & 6,7 & 7,3 \\
\hline Grecja & 8,3 & 7,7 & 9,5 & 12,6 & Rumunia & 6,4 & 5,8 & 6,9 & 7,3 \\
\hline Portugalia & 8,9 & 8,5 & 10,6 & 12,0 & Stowenia & 4,9 & 4,4 & 5,9 & 7,3 \\
\hline Węry & 7,4 & 7,8 & 10,0 & 11,2 & Niemcy & 8,7 & 7,5 & 7,8 & 7,1 \\
\hline Bułgaria & 6,9 & 5,6 & 6,8 & 10,2 & Malta & 6,4 & 5,9 & 7,0 & 6,9 \\
\hline Francja & 8,4 & 7,8 & 9,5 & 9,8 & Cypr & 4,0 & 3,6 & 5,3 & 6,3 \\
\hline UE-27 & $\mathbf{7 , 2}$ & $\mathbf{7 , 1}$ & $\mathbf{9 , 0}$ & $\mathbf{9 , 7}$ & Luksemburg & 4,2 & 4,9 & 5,1 & 4,5 \\
\hline Polska & 9,6 & 7,1 & 8,2 & 9,6 & Holandia & 3,6 & 3,1 & 3,7 & 4,5 \\
\hline Włochy & 6,1 & 6,7 & 7,8 & 8,4 & Austria & 4,4 & 3,8 & 4,8 & 4,4 \\
\hline
\end{tabular}

Źródło: opracowanie własne na podstawie danych Eurostatu, http://appsso.eurostat.ec.europa.eu/nui/show. do?dataset=une_rt_a\&lang=en (dostęp 09.09.2011).

Na czele zestawienia znalazła się Hiszpania z rekordowo wysokim wskaźnikiem bezrobocia na poziomie ponad $20 \%$. Nieco niższą stopę bezrobocia, na poziomie 19-17\%, odnotowały kraje bałtyckie, przy tym największe trudności miały miejsce na rynku pracy Łotwy. Stopę bezrobocia około 14\% zanotowano w Słowacji i Irlandii, około 13\% w Grecji, 12\% w Portugalii, 11\% na Węgrzech i około 10\% w Bułgarii i Francji. Pozostałe 16 państw odnotowało w 2010 roku poziom bezrobocia niższy niż w Unii Europejskiej ogółem.

Najbardziej znacząco poziom bezrobocia w badanym okresie wzrósł w krajach bałtyckich, szczególnie na Litwie - o 13,5 pkt. proc. Następnym krajem, który w czasie kryzysu doświadczył gwałtownego wzrostu bezrobocia, była Hiszpania - wzrost o 11,8 pkt. proc. W Słowacji natomiast stopa bezrobocia już w 2007 roku była na bardzo wysokim poziomie $11 \%$, przy średniej w UE 7,2\%. Dlatego też zmiana wysokości wskaźnika bezrobocia w badanych latach wyniosła tylko 3 pkt. proc., chociaż poziom bezrobocia w 2010 roku był w tym kraju na stosunkowo wysokim poziomie $14 \%$. Dwa kraje członkowskie w omawianym okresie nie doświadczyły zmian w poziomie bezrobocie, tak np. w Polsce stopa bezrobocia w 2010 roku kształtowała się na takim samym poziomie co w 2007 roku - 9,6\%, chociaż należy zauważyć, iż był to stosunkowo wysoki poziom bezrobocia już w 2007 roku w porównaniu 
z resztą krajów unijnych. Również w Austrii w 2010 roku wysokość stopy bezrobocia była na tym samym poziomie co przed kryzysem, tyle że na znacznie niższym niż w Polsce $-4,4 \%$.

\section{Wydatki na politykę rynku pracy}

$\mathrm{Na}$ realizację europejskiej polityki rynku pracy w okresie przedkryzysowym (lata 2005-2007) wydatkowano po około 1,8\% PKB średnio w roku. Intensywność finansowania różniła się w poszczególnych latach, największy udział PKB w finansowaniu działań na rzecz rynku pracy odnotowano w 2005 roku, na poziomie zbliżonym do $2 \%$ PKB. W kolejnych dwóch latach finansowanie systematycznie malało: o 0,17 pkt. proc. w 2006 roku oraz o 0,22 pkt. proc. w 2007 roku.

Tablica 3. Wydatki na finansowanie polityki rynku pracy w UE-27 (w \% PKB)

\begin{tabular}{|l|r|r|r|r|r|}
\hline \multicolumn{1}{|c|}{ Wyszczególnienie } & \multicolumn{1}{c|}{2005} & 2006 & 2007 & 2008 & 2009 \\
\hline Polityka rynku pracy ogółem - LMP & 1,995 & 1,825 & 1,603 & 1,606 & 2,174 \\
\hline Instrumenty aktywne - ALMP & 0,510 & 0,503 & 0,462 & 0,463 & 0,551 \\
\hline Udział ALMP w ogóle wydatków & 25,600 & 27,600 & 28,800 & 28,800 & 25,300 \\
\hline Instrumenty pasywne - PLMP & 1,485 & 1,322 & 1,141 & 1,143 & 1,623 \\
\hline Udział PLMP w ogóle wydatków & 74,400 & 72,400 & 71,200 & 71,200 & 74,700 \\
\hline
\end{tabular}

Źródło: zestawienie własne na podstawie danych Eurostatu, http://epp.eurostat.ec.europa.eu/portal/page/portal/ statistics/search_database (dostęp 06.09.2011).

Kolejny, 2008 rok nie przyniósł znacznych zmian w tym zakresie, udział PKB $\mathrm{w}$ finansowaniu polityki rynku pracy w ugrupowaniu UE-27 pozostawał na poziomie około $1,6 \%$. Istotne zmiany w wysokości finansowania polityki rynku pracy miały miejsce w 2009 roku, gdy wzrosło ono do poziomu około 2,2\% PKB, czyli o 0,6 pkt. proc. $\mathrm{w}$ porównaniu $\mathrm{z}$ rokiem poprzednim.

$\mathrm{W}$ podziale na instrumenty aktywne i pasywne struktura finansowania w czasie kryzysu zmieniała się nieznacznie, chociaż wystąpiły tu także pewne zmiany. W całym badanym okresie na realizację polityki aktywnej wydatkowano się od 25,3\% ogółu środków przeznaczonych na realizację polityki rynku pracy do $28,8 \%$, przeciętnie po około $27,2 \%$ w skali roku. Przy tym należy odnotować spadek udziału środków przeznaczonych na aktywizowanie bezrobotnych w ogóle środków wydatkowanych na politykę rynku pracy w 2009 roku o 3,5 pkt. proc. w porównaniu z rokiem 2008. 
Odwrotna sytuacja wystąpiła w przypadku wydatków na realizację pasywnej polityki rynku pracy. Pierwszy rok kryzysu (2008) nie przyniósł żadnych zmian w wysokości finansowania bezrobotnych w zakresie PLMP, nadal pozostawał on na poziomie nieco ponad $71 \%$ ogółu środków przeznaczanych na realizację LMP. Tym niemniej w następnym roku, podobnie jak w przypadku ALMP, wystąpiła istotna zmiana w wysokości finansowania. W 2009 roku udział środków przeznaczanych na różnego rodzaju wsparcie dla bezrobotnych wzrósł do około $75 \%$.

Konkludując, w okresie kryzysu wzrost środków przeznaczanych na realizację polityki rynku pracy wystąpił tylko w 2009 roku. Jeszcze rok wcześniej osiągały one 1,6\% PKB, czyli kształtowały się na poziomie sprzed kryzysu. Miało także miejsce przesunięcie w strukturze wydatków w stronę finansowania instrumentów polityki pasywnej. W 2009 roku na ALMP wydano tylko 1/4 ogółu środków, natomiast instrumenty pasywne pochłonęły pozostałe $3 / 4$ finansowania.

Należy również odnotować ogromne różnice występujące pomiędzy poszczególnymi krajami pod względem udziału PKB w finansowaniu działań polityki rynku pracy.

Tabela 4. Wydatki publiczne na realizację polityki rynku pracy w latach 2004-2009 w krajach UE (w \% PKB)

\begin{tabular}{|l|l|l|l||l|l|l|l|}
\hline \multicolumn{1}{|c|}{ Państwo } & 2007 & 2008 & 2009 & Państwo & 2007 & 2008 & 2009 \\
\hline Belgia & 3,189 & 3,284 & 3,791 & Estonia & 0,148 & 0,273 & 1,497 \\
\hline Hiszpania & 2,161 & 2,577 & 3,747 & Łotwa & 0,459 & 0,479 & 1,343 \\
\hline Irlandia & 1,614 & 2,101 & 3,473 & Luksemburg & 0,940 & 0,891 & 1,289 \\
\hline Dania & 2,660 & 2,425 & 3,215 & Wegry & 0,625 & 0,639 & 0,977 \\
\hline Holandia & 2,467 & 2,309 & 2,868 & Słowenia & 0,497 & 0,445 & 0,963 \\
\hline Finlandia & 2,257 & 2,138 & 2,771 & Litwa & 0,429 & 0,374 & 0,914 \\
\hline Niemcy & 2,022 & 1,901 & 2,519 & Grecja & 0,503 & 0,619 & 0,909 \\
\hline Francja & 2,169 & 2,010 & 2,397 & Słowacja & 0,586 & 0,692 & 0,895 \\
\hline Austria & 1,921 & 1,832 & 2,349 & Cypr & 0,589 & 0,511 & 0,695 \\
\hline UE-27 & 1,603 & 1,606 & 2,174 & Czechy & 0,458 & 0,422 & 0,663 \\
\hline Portugalia & 1,538 & 1,523 & 2,056 & W. Brytania & 0,480 & 0,462 & 0,661 \\
\hline Szwecja & 1,707 & 1,382 & 1,803 & Bułgaria & 0,481 & 0,454 & 0,651 \\
\hline Włochy & 1,098 & 1,214 & 1,751 & Malta & 0,503 & 0,492 & 0,506 \\
\hline Polska & 1,013 & 0,905 & 1,592 & Rumunia & 0,341 & 0,267 & 0,455 \\
\hline
\end{tabular}

Źródło: opracowanie własne na podstawie danych Eurostatu, http://appsso.eurostat.ec.europa.eu/nui/show. do?dataset=lmp_expsumm\&lang=en (dostęp 02.09.2011). 
$\mathrm{Z}$ dostępnych danych zamieszczonych w tabeli 4 wynika, że w 2008 roku wydatki wahały się od zaledwie 0,3\% PKB w przypadku Estonii lub Rumunii aż do 3,3\% dla Belgii. Można zauważyć, iż „nowe” państwa członkowskie wykazują niższy poziom wydatków niż „stare”, pewien wyjątek stanowi tu Polska z udziałem nieco ponad 0,9\% PKB. Trochę większe środki na politykę rynku pracy w tej grupie krajów przeznaczają Węgry, Grecja i Słowacja - od 0,6\% do 0,7\% PKB. Wśród „starych” krajów również występuje duże zróżnicowanie poziomu wydatków. Powyżej średniej dla całego ugrupowania wydatkuje się w takich krajach, jak Belgia, Hiszpania, Irlandia, Dania, Holandia, Finlandia, Niemcy, Francja i Austria: od 3,3\% PKB w przypadku Belgii do 1,8\% PKB w przypadku Austrii. W tej grupie krajów wydatki mogą też kształtować się na znacznie niższym poziomie, tak np. Luksemburg przeznacza na politykę rynku pracy około 0,9\% PKB, czyli tyle samo co Polska, zaś Wielka Brytania - zaledwie 0,46\% PKB, podobnie jak Bułgaria oraz Słowenia i mniej niż Cypr czy Malta.

Znaczące zróżnicowanie poziomu angażowanych środków pozostawało także w 2009 roku. W dalszym ciągu powyżej średniej unijnej wydatki na aktywne i pasywne instrumenty polityki rynku pracy kształtowały się dla tych samych co w 2008 roku 9 ,starych” krajów. Najwyższy wynik osiągnęła Belgia - około 3,8\% PKB, najniższy Malta i Rumunia - po około 0,5\% PKB.

Porównanie poziomu wydatków na politykę rynku pracy w okresie 2008-2009 pokazuje, iż dla wszystkich krajów członkowskich wystąpił wzrost wspomnianych wartości. Największy przyrost środków odnotowano w przypadku „starych” krajów UE, a mianowicie w Irlandii - o 1,4 pkt. proc. (największa zmiana) oraz Hiszpanii - o 1,1 pkt. proc. W tej grupie krajów również Dania oraz Finlandia dokonały znacznego zwiększenia angażowanych środków, odpowiednio o 0,8\% i o 0,7\% PKB. Istotnie wzrosły wydatki na pasywną i aktywną politykę rynku pracy także w krajach bałtyckich: Estonia odnotowała wzrost środków przeznaczanych na te cele o 1,2 pkt. proc. (żaden inny „,nowy” kraj unijny nie odnotował tak istotnego wzrostu), a Łotwa o 0,8 pkt. proc. (zmiany na poziomie Danii). Wyjątek stanowiła tu Litwa, która zwiększyła poziom finansowania o blisko $0,5 \%$ PKB, podobnie jak uczyniły to Austria czy Portugalia. Najmniejsze zmiany w tym zakresie wystąpiły w Rumunii, Bułgarii, Słowacji i na Malcie, gdzie miał miejsce wzrost zaledwie o 0,2 pkt. proc. Podobna zmiana wystąpiła także w finansowaniu instrumentów polityki rynku pracy w Wielkiej Brytanii. Malta natomiast praktycznie nie odnotowała w 2009 roku żadnych zmian $\mathrm{w}$ poziomie finansowania zarówno $\mathrm{w}$ porównaniu $\mathrm{z}$ rokiem poprzednim, jak i z okresem przedkryzysowym.

Warto przyjrzeć się bliżej wysokości finansowania w zakresie realizacji aktywnej polityki państwa w obrębie poszczególnych państw UE. Jak wynika z zamieszczonych w tabeli 5 danych, tylko 3 kraje finansowały działania aktywizujące bezrobotnych 
na poziomie 1,2\% PKB: Belgia, Dania oraz Polska. Obecność w tej grupie krajów Danii czy Belgii specjalnie nie dziwi, natomiast Polska jest tu pewną niespodzianką. Zresztą, jak wskazują nieskomplikowane obliczenia dotyczące zmian wysokości finansowania polityki ALMP w okresie 2007-2009, Polska jest krajem, który w czasie kryzysu najbardziej zwiększył finansowanie aktywnych narzędzi rynku pracy - aż o 0,8 pkt. proc. Żaden inny kraj nie odnotował tak istotnych zmian w tym okresie.

Tabela 5. Finansowanie aktywnych instrumentów polityki rynku pracy (w \% PKB)

\begin{tabular}{|l|l|l|l||l|l|l|l|}
\hline \multicolumn{1}{|c|}{ Państwo } & 2007 & 2008 & 2009 & Państwo & 2007 & 2008 & 2009 \\
\hline Belgia & 0,980 & 1,082 & 1,191 & Węgry & 0,183 & 0,185 & 0,358 \\
\hline Dania & 1,020 & 0,977 & 1,174 & Włochy & 0,369 & 0,365 & 0,335 \\
\hline Polska & 0,404 & 0,468 & 1,157 & Łotwa & 0,108 & 0,078 & 0,272 \\
\hline Holandia & 0,722 & 0,715 & 0,786 & Słowenia & 0,111 & 0,093 & 0,230 \\
\hline Finlandia & 0,706 & 0,672 & 0,752 & Bułgaria & 0,286 & 0,253 & 0,224 \\
\hline Francja & 0,708 & 0,634 & 0,722 & Grecja & 0,152 & 0,142 & 0,212 \\
\hline Szwecja & 0,871 & 0,645 & 0,670 & Litwa & 0,228 & 0,139 & 0,200 \\
\hline Austria & 0,511 & 0,514 & 0,668 & Słowacja & 0,116 & 0,150 & 0,150 \\
\hline Irlandia & 0,486 & 0,546 & 0,653 & Estonia & 0,028 & 0,035 & 0,149 \\
\hline Hiszpania & 0,627 & 0,605 & 0,652 & Czechy & 0,120 & 0,104 & 0,094 \\
\hline Portugalia & 0,372 & 0,407 & 0,629 & Cypr & 0,081 & 0,062 & 0,066 \\
\hline Niemcy & 0,463 & 0,511 & 0,627 & W. Brytania & 0,048 & 0,047 & 0,045 \\
\hline UE-27 & 0,462 & 0,463 & 0,551 & Rumunia & 0,076 & 0,060 & 0,041 \\
\hline Luksemburg & 0,376 & 0,325 & 0,373 & Malta & 0,032 & 0,049 & 0,030 \\
\hline
\end{tabular}

Źródło: opracowanie własne na podstawie danych Eurostatu, http://appsso.eurostat.ec.europa.eu/nui/show. do?dataset=lmp_expsumm\&lang=en (dostęp 03.10.2011).

Finansowanie aktywnych instrumentów polityki rynku pracy na poziomie od 0,8\% do 0,7\% PKB odnotowano w 7 krajach unijnych: Holandii, Finlandii, Francji, Szwecji, Austrii, Irlandii oraz Hiszpanii. Następne 2 kraje, Portugalia oraz Niemcy, mieszczą się w granicach finansowania na poziomie około 0,6\% PKB. Są to też kraje, które bardzo znacząco zwiększyły w czasie kryzysu finansowanie na te działania w zakresie LMP. Wszystkie wymienione kraje legitymują się wydatkami na ALMP w 2009 roku powyżej średniej unijnej, kształtującej się na poziomie 0,551\% PKB.

Pozostałe kraje członkowskie można podzielić na dwie grupy. Do pierwszej zostały zaliczone kraje, których poziom wydatków mieści się w granicach od 0,4\% do $0,1 \%$ PKB. W tej grupie znalazło się większość „nowych” krajów członkowskich: Litwa, Łotwa, Czechy, Węgry, Słowenia, Bułgaria, Słowacja Estonia oraz Cypr, ale także Włochy czy Luksemburg. W drugiej grupie krajów, które wykazują najniższe 
zaangażowanie środków publicznych na realizację aktywnej polityki (poniżej 0,1\% PKB), znalazły się tradycyjnie Rumunia oraz Malta, ale także Wielka Brytania.

Z przedstawionego zestawienia wynika, że w czasie kryzysu na aktywizację bezrobotnych zwiększono finansowanie w 18 krajach UE. Najbardziej dotyczy to Polski, ale również Portugalii i Węgier. W 3 krajach finansowanie pozostało na tym samym lub bardzo podobnym poziomie co przed kryzysem, są to Luksemburg, Malta oraz Wielka Brytania i dla kolejnych 7 krajów wystąpiło znaczne obniżenie środków przydzielanych na te cele. Największego obcięcia wydatków na aktywizację bezrobotnych doświadczyła Szwecja, gdzie udział finansowania ALMP obniżył się o 0,2 pkt. proc. w 2009 roku w porównaniu z 2007 rokiem.

Do interpretowania poziomu finansowania aktywnej polityki rynku pracy i jego zmian w czasie kryzysu należy podchodzić z pewną ostrożnością, ponieważ pasywne i aktywne formy można uznać za komplementarne, ale także i ze względu na istniejące zróżnicowanie w klasyfikacji poszczególnych działań na rynku pracy. Tak np. brak jednoznacznej opinii na temat klasyfikacji wydatków z tytułu wprowadzenia systemu skróconego czasu pracy. W przypadku Eurostatu powyższe wydatki są klasyfikowane jako wydatki z zakresu PLMP, ponieważ skierowane są do osób mających miejsce pracy, a nie do bezrobotnych. Rozmaicie natomiast są one ujmowane w klasyfikacjach krajowych, co świadczy o tym, że różnić się też będą dane statystyczne w podziale na pasywne i aktywne środki finansowane przez poszczególne państwa. ${ }^{3}$

Tym niemniej można z pewnością mówić o tym, że - generalnie rzecz ujmując w zakresie wysokości finansowania polityki rynku pracy przodują ,stare” kraje UE, z wyjątkiem Wielkiej Brytanii i w mniejszym stopniu Luksemburga. „Nowe” kraje członkowskie pozostają w tyle, w znacznym stopniu z powodu stosunkowo słabiej rozwiniętego systemu aktywnych środków rynku pracy. Wyjątek stanowi tu Polska, która poziomem nakładów na działania aktywne dorównuje „starszym” państwom członkowskim. Jest to być może jeden z czynników odpowiadających za imponujące wyniki polskiego rynku pracy w ostatnich latach. Nie należy w tym przypadku zapominać o bardzo korzystnych uwarunkowaniach makroekonomicznych, jakie miały miejsce w tym kraju w czasach ogólnego załamania w większości krajów europejskich.

$\mathrm{Z}$ drugiej strony zmniejszenie lub niezwiększanie wydatków na ALMP mogło wynikać z ogólnej polityki kraju dotyczącej działań na rynku pracy. Otóż mogły one uważać, iż w czasach wysokiego bezrobocia i braku popytu na pracę nie warto inwestować w aktywizację bezrobotnych (np. w postaci szkoleń), ponieważ owo bezrobocie nie wynika z niedopasowania popytu i podaży, lecz z braku popytu na

${ }^{3}$ Szerzej na ten temat w: Finansowanie i funkcjonowanie aktywnych programów rynku pracy w czasach kryzysu, Raport Centrum Monitorowania Rynku Pracy przy Europejskim Komitecie Ekonomiczno-Społecznym, 2010, http://www.eurofound.europa.eu/publications/htmlfiles/ef1066_pl.htm (dostęp 05.09.2011). 
siłę roboczą. Tak np. w przypadku Szwecji widać, że w okresie 2008-2009 wydatki na LMP zostały zwiększone o $0,5 \%$ PKB, natomiast w tym czasie wydatki na ALMP spadły o 0,2\% PKB. Można więc wnioskować, iż rząd Szwecji uznał, że w czasach kryzysu inwestycje aktywizacyjne są mniej opłacalne z punktu widzenia ponownego zatrudnienia bezrobotnych. W tym kontekście zrozumiała jest polityka Polski, skierowana na aktywizację bezrobotnych, którzy mają duże szanse znalezienia pracy, ponieważ sektor przedsiębiorstw generuje nowe miejsca pracy i oddaje preferencje bardziej doświadczonej sile roboczej o określonych umiejętnościach i kwalifikacjach.

W zakresie ALMP rządy podejmują różne działania, w tabeli 6 przedstawiono wydatki Unii Europejskiej na poszczególne instrumenty aktywizujące.

Tabela 6. Wydatki UE-27 w podziale na rodzaje działań (w \% ogółu wydatków)

\begin{tabular}{|l|r|r|r|r|r|c|}
\hline \multicolumn{1}{|c|}{ Działanie } & 2005 & 2006 & 2007 & 2008 & 2009 & Zmiany 2007-2009 \\
\hline Szkolenia & 38,0 & 39,3 & 38,0 & 38,4 & 42,6 & $+4,60$ \\
\hline Zachęty do zwiększania zatrudnienia & 24,4 & 24,8 & 25,7 & 25,0 & 23,8 & $-1,90$ \\
\hline $\begin{array}{l}\text { Zatrudnienie wspierane } \\
\text { i rehabilitacja zawodowa }\end{array}$ & 17,3 & 12,9 & 13,8 & 15,8 & 14,4 & $+0,60$ \\
\hline Bezpośrednie tworzenie miejsc pracy & 13,4 & 14,4 & 14,9 & 13,4 & 12,1 & $-2,80$ \\
\hline $\begin{array}{l}\text { Zachetty do podejmowania } \\
\text { działalności gospodarczej }\end{array}$ & 6,3 & 7,9 & 7,1 & 7,0 & 6,8 & $-0,30$ \\
\hline $\begin{array}{l}\text { Zatrudnienie rotacyjne } \\
\text { i dzielenie stanowisk pracy }\end{array}$ & 0,6 & 0,7 & 0,5 & 0,43 & 0,36 & $-0,14$ \\
\hline Ogółem & 100,0 & 100,0 & 100,0 & 100,0 & 100,0 & \\
\hline
\end{tabular}

Źródło: opracowanie własne na podstawie danych Eurostatu, http://epp.eurostat.ec.europa.eu/tgm/refreshTableAction. do?tab=table\&plugin $=0 \&$ pcode $=$ tps00077\&language $=$ en $($ dostęp 15.09.2011).

Ogólnie rzecz ujmując, można powiedzieć, iż największą część wydatków (około 40\%) przeznaczonych na realizację ALMP pochłaniają różnego rodzaju szkolenia (np. instytucjonalne, w miejscu pracy i inne). Około 1/4 wydatków (24-25\%) przeznacza się na zachęty do zwiększania zatrudnienia (w tym dotacje dla zatrudniających). Dwoma kolejnymi rodzajami działań o znacznym (16-13\%) udziale w wydatkach na aktywne działania są zatrudnienie wspierane i rehabilitacja zawodowa, mające na celu przede wszystkim integrację osób o ograniczonej zdolności do pracy, oraz wydatki na bezpośrednie tworzenie miejsc pracy, w ramach których ma miejsce dotowanie tymczasowych, pozarynkowych miejsc pracy, które nie powstałyby bez interwencji publicznej. Instrumentom zachęcającym do podejmowania działalności, w tym tworzenia nowych przedsiębiorstw lub samozatrudnienia, przypisuje się znacznie mniejszą rolę wśród aktywizujących instrumentów i w czasie kryzysu przeznaczało się na ich realizację zaledwie około $7 \%$ ogółu wydatków. 
Całkiem marginalne znaczenie, sądząc z wysokości finansowania, przyznano zatrudnieniu rotacyjnemu i dzieleniu istniejących miejsc pracy oraz czasu pracy na większą liczbę zatrudnionych. System ten polega na obsadzaniu danego stanowiska więcej niż jednym pracownikiem i dzielenie między pracowników zadań wykonywanych na tym stanowisku. Na ww. instrument przeznaczano w czasach kryzysu zaledwie $0,3-0,4 \%$ PKB, chociaż w okresie przedkryzysowym cieszył się on większym zainteresowaniem. Zresztą w czasie kryzysu finansowanie wzrosło tylko dla dwóch instrumentów: szkoleń oraz zatrudnienia wspieranego i rehabilitacji zawodowej. W przypadku szkoleń wysokość finansowania wzrosła aż o 4,6 pkt. proc. w okresie 2007-2009. Na pierwszy rzut oka jest to nieco dziwne, iż w okresie permanentnego braku miejsc pracy zwiększa się udział publicznych środków kierowanych na stymulowanie strony podażowej rynku pracy. Dalsza analiza pokazała jednak, że wspomniane środki były kierowane przede wszystkim do osób bezrobotnych znajdujących się w szczególnie trudnej sytuacji na rynku pracy lub na wspieranie programów branżowych, przeznaczonych na przekwalifikowanie zawodowe osób zatrudnionych w niektórych sektorach gospodarki, takich jak np. motoryzacyjny lub budowlany, które okazały się najbardziej wrażliwe na kryzys gospodarczy. Nie należy także zapominać, że w przypadku „,nowych” krajów członkowskich dochodzi jeszcze problem niedopasowania strukturalnego znacznej części zasobów pracy do zmieniających się potrzeb gospodarki, szczególnie w czasie gwałtownych zmian wywołanych recesją, co również mogło mieć wpływ na strukturę wydatków w zakresie działań aktywizujących.

Pasywna polityka rynku pracy obejmuje świadczenia i pomoc dla bezrobotnych, jak również wcześniejsze emerytury. W całej Unii Europejskiej z tego rodzaju świadczeń korzystało w 2009 roku ponad $18 \mathrm{mln}$ bezrobotnych (tabela 7), przeważająca większość (ponad 94\%) to osoby pobierające zasiłki. Jest to najczęściej wykorzystywane narzędzie pasywnej polityki rynku pracy. Tylko nieco ponad 1 mln osób skorzystało z możliwości przejścia na wcześniejszą emeryturę. Liczba beneficjentów korzystających ze świadczeń emerytalnych i pomocy dla bezrobotnych w obrębie PLMP znacznie się różniła dla poszczególnych państw członkowskich. 
Tabela 7. Beneficjenci pasywnej polityki rynku pracy według rodzajów świadczeń (w tys.)

\begin{tabular}{|c|c|c|c|c|c|c|c|}
\hline Państwo & 2007 & 2008 & 2009 & Państwo & 2007 & 2008 & 2009 \\
\hline \multicolumn{4}{|l|}{ UE-27 } & Grecja & & & \\
\hline Ogółem, w tym & 13097 & 13361 & 18173 & Ogółem, w tym & : & 219 & 272 \\
\hline Zasiłki & 11788 & 12234 & 17124 & Zasitki & : & 219 & 272 \\
\hline Emerytury & 1309 & 1127 & 1050 & Emerytury & - & - & - \\
\hline \multicolumn{4}{|l|}{ Niemcy } & Szwecja & & & \\
\hline Ogółem, w tym & 3579 & 3200 & 4390 & Ogółem, w tym & 260 & 197 & 253 \\
\hline Zasitki & 3475 & 3100 & 4295 & Zasitki & 260 & 197 & 253 \\
\hline Emerytury & 104 & 100 & 95 & Emerytury & - & - & - \\
\hline \multicolumn{4}{|l|}{ Hiszpania } & Węgry & & & \\
\hline Ogółem, w tym & 1421 & 1814 & 2681 & Ogółem, w tym & 140 & 155 & 239 \\
\hline Zasilki & 1421 & 1815 & 2681 & Zasitki & 139 & 155 & 239 \\
\hline Emerytury & - & - & - & Emerytury & 1 & 0,5 & - \\
\hline \multicolumn{4}{|l|}{ Francja } & Czechy & & & \\
\hline Ogółem, w tym & 2260 & 2281 & 2379 & Ogółem, w tym & 116 & 109 & 188 \\
\hline Zasilki & 2200 & 2242 & 2355 & Zasitki & 116 & 109 & 188 \\
\hline Emerytury & 60 & 39 & 24 & Emerytury & - & - & - \\
\hline \multicolumn{4}{|l|}{ Włochy } & Dania & & & \\
\hline Ogółem, w tym & 996 & 1095 & 1669 & Ogółem, w tym & 166 & 129 & 174 \\
\hline Zasiłki & 655 & 765 & 1348 & Zasitki & 104 & 73 & 126 \\
\hline Emerytury & 341 & 330 & 321 & Emerytury & 62 & 56 & 48 \\
\hline \multicolumn{4}{|l|}{ W. Brytania } & Bułgaria & & & \\
\hline Ogółem, w tym & 839 & 1022 & 1583 & Ogółem, w tym & 63 & 67 & 124 \\
\hline Zasitki & 839 & 1022 & 1583 & Zasitki & 63 & 67 & 124 \\
\hline Emerytury & - & - & - & Emerytury & - & - & - \\
\hline \multicolumn{4}{|l|}{ Belgia } & Słowacja & & & \\
\hline Ogółem, w tym & 816 & 806 & 907 & Ogółem, w tym & 70 & 80 & 107 \\
\hline Zasiłki & 594 & 589 & 694 & Zasiłki & 22 & 22 & 50 \\
\hline Emerytury & 222 & 217 & 213 & Emerytury & 48 & 58 & 56 \\
\hline \multicolumn{4}{|l|}{ Holandia } & Litwa & & & \\
\hline Ogółem, w tym & 556 & 540 & 670 & Ogółem, w tym & 18 & 23 & 70 \\
\hline Zasilki & 556 & 540 & 670 & Zasitki & 18 & 23 & 70 \\
\hline Emerytury & - & - & - & Emerytury & - & - & - \\
\hline \multicolumn{4}{|l|}{ Polska } & Łotwa & & & \\
\hline Ogółem, w tym & 578 & 455 & 536 & Ogółem, w tym & 32 & 31 & 63 \\
\hline Zasitki & 251 & 271 & 380 & Zasitki & 32 & 31 & 63 \\
\hline Emerytury & 327 & 184 & 156 & Emerytury & - & - & - \\
\hline
\end{tabular}




\begin{tabular}{|l|c|c|c||l|c|c|c|}
\hline \multicolumn{1}{|c|}{ Państwo } & 2007 & 2008 & 2009 & Państwo & 2007 & 2008 & 2009 \\
\hline Irlandia & & & & Stowenia & & & \\
\hline Ogółem, w tym & 164 & 229 & 428 & Ogółem, w tym & 18 & 15 & 62 \\
\hline Zasiłki & 153 & 220 & 420 & Zasiłki & 18 & 15 & 62 \\
\hline Emerytury & 11 & 9 & 7 & Emerytury & - & - & - \\
\hline Portugalia & & & & Estonia & & & \\
\hline Ogółem, w tym & 306 & 253 & 367 & Ogółem, w tym & 9 & 12 & 40 \\
\hline Zasiłki & 277 & 220 & 336 & Zasiłki & 9 & 12 & 40 \\
\hline Emerytury & 29 & 34 & 31 & Emerytury & - & - & - \\
\hline Rumunia & & & & Luksemburg & & & \\
\hline Ogółem, w tym & 165 & 128 & 325 & Ogółem, w tym & 8 & 9 & 19 \\
\hline Zasiłki & 165 & 128 & 325 & Zasiłki & 7 & 8 & 18 \\
\hline Emerytury & - & - & - & Emerytury & 1 & 1 & 1 \\
\hline Austria & & & & Cypr & & & \\
\hline Ogółem, w tym & 258 & 246 & 320 & Ogółem, w tym & 9 & 9 & 13 \\
\hline Zasiłki & 202 & 195 & 272 & Zasiłki & 9 & 9 & 13 \\
\hline Emerytury & 56 & 51 & 47 & Emerytury & - & - & - \\
\hline Finlandia & & & & Malta & & & \\
\hline Ogółem, w tym & 240 & 227 & 284 & Ogółłem, w tym & 10 & 10 & 11 \\
\hline Zasiłki & 194 & 179 & 235 & Zasiłki & 10 & 10 & 11 \\
\hline Emerytury & 46 & 48 & 50 & Emerytury & - & - & - \\
\hline
\end{tabular}

Źródło: opracowanie własne na podstawie danych Eurostatu, http://epp.eurostat.ec.europa.eu/tgm/table.do?ta$\mathrm{b}=$ table\&init $=1$ \&language $=$ en \&pcode $=$ tps00080\&plugin $=1($ dostęp 02.10.2011 $)$.

W Niemczech z tego rodzaju pomocy korzystało w 2009 roku ponad 4 mln osób, w Hiszpanii około 3 mln bezrobotnych, we Francji ponad $2 \mathrm{mln}$, we Włoszech i Wielkiej Brytanii liczba ta kształtowała się na poziomie około 1,5 mln osób. Na drugim końcu bieguna znajdowały się takie kraje, jak Malta czy Cypr, gdzie liczba beneficjentów pomocy ze środków publicznych kształtowała się na poziomie nieco przekraczającym 10 tys.

Zarówno w całym ugrupowaniu, jak i w większości krajów członkowskich w czasie kryzysu miał miejsce wzrost liczby bezrobotnych korzystających z pomocy. W całej UE liczba wspieranych osób wzrosła w badanym okresie o ponad $5 \mathrm{mln}$, natomiast najbardziej istotne przyrosty w tym zakresie miały miejsce w: Hiszpanii o ponad 1 mln osób, Niemczech, Wielkiej Brytanii i Włoszech - po 700-800 tys. oraz w Grecji, Irlandii i Rumunii - na poziomie około 200 tys. W 2 krajach miał miejsce spadek liczby bezrobotnych korzystających z zasiłków i wcześniejszych emerytur. W przypadku Szwecji w badanym okresie liczba wspieranych bezrobotnych zmalała o blisko 7 tys. osób, natomiast najbardziej imponującego spadku beneficjentów 
PLMP doświadczyła Polska, co można tłumaczyć sukcesami tego kraju zarówno w polityce gospodarczej ogółem, jak i w zakresie prowadzonej polityki rynku pracy.

Ogromne przyrosty liczby bezrobotnych korzystających ze wsparcia socjalnego ze środków publicznych w przypadku takich krajów, jak Grecja, Hiszpania, Włochy, Rumunia czy Irlandia w dużej mierze zostały spowodowane wysokim poziomem bezrobocia i ogromną liczbą bezrobotnych wymagających opieki. W przypadku Niemiec uwzględnić jeszcze należy zakres stosowania narzędzi polityki pasywnej, mierzony liczbą beneficjentów uprawnionych do pobierania zasiłków oraz okresem czasowym tego wsparcia, który z pewnością jest znacznie szerszy niż w przypadku wyżej wymienionych krajów.

Budżety pasywnej polityki rynku pracy rosły od 2008 roku w krajach doświadczających gwałtownego wzrostu bezrobocia, takich jak Hiszpania, kraje bałtyckie czy Irlandia. W sytuacji, gdy w tych krajach poziom bezrobocia wzrósł ponad trzykrotnie w ciągu ostatnich trzech lat, budżety działań pasywnych zazwyczaj zwiększały się o taki sam współczynnik, tym samym odzwierciedlając, że żyjącym w nich bezrobotnym przysługiwały świadczenia z tytułu pozostawania bez pracy. Wyżej wymienione kraje w poszukiwaniu kompromisu pomiędzy nakładami na działania aktywne i pasywne zazwyczaj obniżały poziom uczestnictwa bezrobotnych w działaniach aktywnych np. poprzez cięcie wydatków na droższe szkolenia.

Interesujących informacji dostarczają również zamieszczone $\mathrm{w}$ tabeli 7 dane dotyczące liczby beneficjentów korzystających ze wsparcia $\mathrm{z}$ tytułu wcześniejszych emerytur, adresowanych do osób starszych, które podjęły decyzję o wycofaniu się z rynku pracy. Należy odnotować, iż w całej UE liczba bezrobotnych korzystających ze wsparcia ze środków publicznych w omawianym okresie wzrosła o 5076 tys., natomiast osób korzystających z zasiłków o 5336 tys., co oznacza przesunięcie ciężaru płatności w ramach polityki PLMP w kierunku zasiłków. Potwierdzają to zresztą dane dotyczące kształtowania się wysokości płatności z tytułu wcześniejszych emerytur: w 2009 roku wystąpił spadek beneficjentów o blisko 260 tys. w porównaniu $\mathrm{z}$ rokiem 2007. Ten instrument pasywnej polityki rynku pracy nie cieszył się popularnością, ponad połowa krajów członkowskich w ogóle go nie stosowała - Hiszpania, Grecja, Szwecja, Czechy, Wielka Brytania, Bułgaria, Holandia, Litwa, Łotwa, Estonia, Słowenia, Rumunia, Cypr i Malta. Niektóre z tej grupy krajów wcześniej używały tego instrumentu (np. Litwa do 2006 roku, Szwecja do 2002 roku, Czechy do 2003 roku), lecz później zaprzestały. Największą liczbę osób korzystających z dopłat z tego tytułu zanotowano we Włoszech (321 tys. w 2009 roku), Belgii (213 tys.) oraz Polsce (156 tys.), tym niemniej we wszystkich wymienionych krajach odnotowano spadek liczby beneficjentów w badanym okresie, szczególnie dotyczy to Polski, gdzie wystąpiło zmniejszenie omawianego wskaźnika o ponad 50\%. 


\section{Programy antykryzysowe i ich efektywność}

Wysiłek przezwyciężenia kryzysu poprzez planowanie i konkretne działania podjęto zarówno w skali krajów, jak i na poziomie międzynarodowym. W pierwszej fazie kryzysu działania państw członkowskich były słabo skoordynowane. Pierwsze problemy zostały rozwiązane w grudniu 2008 roku, kiedy to RE przyjęła koncepcję walki z kryzysem finansowym. Została wówczas zaproponowana koordynacja działań podejmowanych w celu przeciwdziałania negatywnym konsekwencjom kryzysu w postaci Europejskiego Planu Naprawy Gospodarczej (European Economic Recovery Plan) oraz szeregu wspólnych działań opartych na strategii lizbońskiej. ${ }^{4}$ Plan ten zakładał przekazanie w najbliższych latach kwoty rzędu 200 mld euro na potrzeby unijnej gospodarki, co stanowiło 1,5\% wspólnotowego PKB. Większość środków (170 mld euro) miała pochodzić z budżetów państw członkowskich, pozostała zaś część będzie sfinansowana z budżetu UE oraz Europejskiego Banku Inwestycyjnego.

Plany naprawcze pojawiły się także w większości państw Unii pod koniec 2008 roku lub w pierwszej połowie 2009 roku. W wydanym w 2009 roku komunikacie Komisji Europejskiej podano liczbę 500 działań i programów, które w dobie kryzysu zostaną wdrożone w państwach członkowskich UE. ${ }^{5} \mathrm{Z}$ tego $16 \%$ to programy skierowane na wspierania prawidłowego funkcjonowania rynków pracy. Generalnie można powiedzieć, iż pakiety działań antykryzysowych były skierowane na ograniczenie negatywnych skutków recesji gospodarczej. Działania podejmowane w tym zakresie przez państwa członkowskie obejmowały bezpośrednie tworzenie miejsc pracy, pomoc w podjęciu działalności na własny rachunek czy też subsydiowanie zatrudnienia, co pozwoliło pracodawcom na redukcję kosztów zatrudnienia w warunkach załamania koniunktury na rynku. ${ }^{6}$

Ważną rolę w programach LMP odgrywały też środki stymulujące mobilność przestrzenną siły roboczej. Refundacja kosztów zatrudnienia lub szkoleń poza miejscem zamieszkania z założenia miała stymulować wzrost produktywnego zatrudnienia bezrobotnych oraz weryfikować ich gotowość do podjęcia pracy. Państwa członkowskie podjęły także szereg działań w celu ochrony istniejących miejsc pracy oraz

\footnotetext{
4 European Commission, A European Economic Recovery Plan, COM 2008, Brussels, http://ec.europa. eu/economy_finance/publications/publication13504_en.pdf (dostęp 02.09.2011).

${ }_{5}$ Communication for the Spring European Council, Driving European Recovery, Vol. 2, Annex II, COM 2009, European Commission, Brussels 2009, s. 7, http://www.europa-nu.nl/9353000/1/j4nvgs5kjg27kof_ j9vvikqpopjt8zm/vi7jgtb2sini/f=/.pdf (dostęp 07.10.2011).

${ }^{6}$ Informacja dotyczaca działań antykryzysowych podejmowanych $w$ wybranych krajach świata, Ministerstwo Gospodarki, Warszawa 2009, s. 3, http://www.e-rachunkowosc.pl/materialy/MG_polityka-antykryzysowa-na-swiecie.pdf (dostęp 03.08.2011).
} 
integracji zawodowej osób bezrobotnych. W literaturze przedmiotu można spotkać opinie, iż przeważająca większość podejmowanych działań stanowi w istocie rozwinięcie wcześniej funkcjonujących instrumentów polityki rynku pracy, prowadzonej zgodnie z zasadami odnowionej strategii lizbońskiej.?

Jednym z problemów stwierdzonych $\mathrm{w}$ dotychczasowym procesie realizacji polityki ALMP jest mnogość i różnorodność instrumentów. Pociąga to za sobą konieczność dzielenia budżetu na tak wiele działań, że w efekcie niektóre interwencje ALMP prowadzone są na małą skalę i mają wycinkowy charakter. Zresztą określenie realnych efektów programów rynku pracy jest niezmiernie trudne, ponieważ należy porównać faktycznie osiągnięte wyniki z wynikami możliwymi do uzyskania, gdyby takie programy nie byłyby realizowane. Częstokroć jest to niemożliwe bądź z braku odpowiednich danych, bądź ich fragmentaryzmu. Odnotować także należy, iż istnieje wiele różnych działań mieszczących się w szerokiej kategorii ALMP i skierowanych często do określonych grup odbiorców: młodzieży, osób, które niedawno utraciły pracę, długotrwale bezrobotnych, osób w starszym wieku, kobiet, obcokrajowców itd. Poza tym ocena efektywności poszczególnych jej narzędzi może być prowadzona zarówno w skali mikroekonomicznej, jak i makroekonomicznej, przy tym skuteczność poszczególnych programów na tych poziomach nie musi być tożsama. Dostępne analizy zazwyczaj dokonywane są w oparciu o punkt odniesienia, jakim jest stan zatrudnienia osób objętych działaniem danego instrumentu, po upływie określonego czasu. Instrument jest tym skuteczniejszy, im wyższa jest stopa ponownego zatrudnienia uczestników programu.

$\mathrm{Z}$ punktu widzenia obranej tematyki interesujące byłyby uwagi na temat skuteczności ALMP w czasie recesji gospodarczej. Ważne w tym kontekście informacje zawiera opracowanie Narodowego Biura Badań Ekonomicznych pt. Active Labor Market Policy evaluations: a meta-analysis z lipca $2010 \mathrm{roku}^{8}{ }^{8} \mathrm{~W}$ opracowaniu poddano analizie około 100 programów zrealizowanych w 26 różnych krajach, w tym w krajach członkowskich UE. Autorzy raportu doszli do wniosku, iż efektywność programów w zakresie ALMP należy oceniać w perspektywie długoterminowej, ponieważ wówczas jest większe prawdopodobieństwo wystąpienia znacznych pozytywnych efektów w zakresie zatrudnienia, np. dwa-trzy lata po udziale w programie. W krótkim okresie, np. roku, efekty te najczęściej nie występują lub występują w bardzo ograniczonym zakresie. Bardzo nisko (w porównaniu $\mathrm{z}$ innymi programami ALMP) została tu oceniona efektywność programów dotowania zatrudnienia

7 T. Mering, Programy antykryzysowe w krajach Unii Europejskiej, w: M. Księżopolski, B. Rysz-Kowalczyk, C. Żołędowski, Polityka społeczna w kryzysie, Oficyna Wydawnicza ASPRA-JR, Warszawa 2009, s. 215-217.

8 D. Card, J. Kluve, A. Weber, Active Labor Market Policy evaluations: a meta-analysis, ,,NBER Working Paper Series", Cambridge 2010, http://www.nber.org/papers/w16173.pdf (dostęp 13.09.2011). 
w sektorze publicznym. Z opracowania wynika również, iż takie czynniki, jak kraj lub grupa docelowa beneficjentów w bardzo nieznacznym stopniu decydują o skuteczności poszczególnych programów. Decydujący jest natomiast rodzaj realizowanego programu. Wskazuje się tu na potrzebę uwzględnienia w analizie nie tylko zmian w poziomie zatrudnienia (jak to czyni się w większości tego rodzaju badań), lecz także w poziomie zarobków beneficjentów po udziale w programie, należy też uwzględnić koszty realizacji takich programów. Tylko kompleksowa długoterminowa analiza wyników i kosztów pozwoli wnioskować o skuteczności aktywizujących instrumentów.

We wspomnianym wcześniej opracowaniu Finansowanie i funkcjonowanie aktywnych programów rynku pracy $w$ czasach kryzysu są przedstawione raporty krajowe z lipca i sierpnia 2010 roku z kilku krajów Sieci Obserwatoriów Europejskich (NEO), ${ }^{9}$ na których podstawie także można wnioskować na temat skuteczności aktywnej polityki rynku pracy. Wynika z nich bowiem, iż programy szkoleń uznawane są za skuteczniejsze od programów bezpośredniego tworzenia miejsc pracy (Słowacja), świadczenie usług aktywizacyjnych jest bardziej skuteczne w przypadku osób w wieku 30-50 lat, posiadających wykształcenie wyższe. Natomiast programy skierowane do grup szczególnie zagrożonych na rynku pracy są zdaniem korespondentów krajowych mniej efektywne (Bułgaria). W Szwecji wysoko oceniono skuteczność działania publicznych służb zatrudnienia w zakresie pośrednictwa pracy dla osób długotrwale bezrobotnych. Litwa natomiast odnotowała pogorszenie skuteczności ALMP, mierzonej wskaźnikiem ponownego zatrudnienia, z powodu kryzysu gospodarczego.

Można tu także spotkać i krytyczne uwagi na temat prowadzonych badań efektywności aktywnych programów rynku pracy, dotyczące m.in. okresu analizy (Dania), czy też porównywania kosztów realizacji programu i osiągniętych wyników (Irlandia).

\section{Wnioski}

Konkludując, można powiedzieć, że wydatki na aktywne i pasywne instrumenty polityki rynku pracy w czasie kryzysu charakteryzowały się tendencją wzrostową we wszystkich krajach członkowskich. Miało natomiast miejsce znaczne zróżnicowanie poziomu tych zmian dla poszczególnych krajów. Największy przyrost

\footnotetext{
9 Finansowanie i funkcjonowanie..., op.cit., s. 6.
} 
środków w badanym okresie odnotowano w przypadku „starych” krajów UE, a mianowicie w Irlandii oraz Hiszpanii, ale także Danii i Finlandii.

Przeważającą część wydatków w ramach LMP przeznacza się na realizację pasywnej polityki rynku pracy, na poziomie około $75 \%$ ogółu wydatków. W czasie dekoniunktury gospodarczej znacznie wzrosła liczba beneficjentów korzystających z pomocy w ramach pasywnej polityki rynku pracy, o ponad $5 \mathrm{mln}$ osób w całej UE. Jednocześnie nastąpił wzrost liczby bezrobotnych korzystających z zasiłków dla bezrobotnych i spadek liczby beneficjentów dopłat z tytułu wcześniejszych emerytur. To ostatnie narzędzie było mało popularne wśród krajów członkowskich i zaledwie połowa $\mathrm{z}$ nich korzystała $\mathrm{z}$ niego $\mathrm{w}$ badanym okresie.

W zakresie finansowania aktywnej polityki rynku pracy 3 kraje - Belgia, Dania oraz Polska - przeznaczały w badanym okresie szczególnie wysokie finansowanie publiczne, sięgające 1,2\% PKB. Generalnie można powiedzieć, iż wysokość finansowania środków aktywnej polityki rynku pracy była bardziej znacząca w przypadku „starych” krajów członkowskich, ,nowe” (z wyjątkiem Polski) przeznaczały na te cele od $0,4 \%$ do $0,1 \%$ PKB. W obrębie wydatków na ALMP około $40 \%$ jest przeznaczane na aktywizację bezrobotnych za pomocą różnego rodzaju szkoleń i dokształcania. Najmniejsze finansowanie było przeznaczane na zatrudnienie rotacyjne oraz podział miejsca pracy, zaledwie $0,4 \%$ PKB.

Skuteczność stosowanych instrumentów ocenia się różnie w różnych krajach członkowskich. Zapewne potrzebny jest dłuższy czas do przeprowadzenia rzetelnej analizy efektywności polityki rynku pracy w dobie kryzysu. Warto także pamiętać, iż mimo wprowadzania coraz to nowszych rozwiązań w dziedzinie polityki rynku pracy zakres jej oddziaływania pozostaje ograniczony. Polityka rynku pracy jedynie wspiera i uzupełnia walkę z bezrobociem, która jest prowadzona przede wszystkim w sferze ekonomicznej (wzrost gospodarczy, tworzenie nowych miejsc pracy). Nawet najbardziej rozbudowane instrumenty skierowane na aktywizację zawodową oraz pomoc w przetrwaniu trudności i przeciwdziałanie likwidacji miejsc pracy nie zwalczą bezrobocia, mogą one jedynie ograniczyć rozmiary i skutki społeczne tego zjawiska. 


\section{Functioning and financing of European Labour Market Policy in the times of world economic crisis}

Labour market policy is considered an element of state intervention in market mechanisms as consequence of negative labour market phenomena. Downturn on labour market caused by global economic crisis has led to increase in the number of tasks of LMP aimed at protection of existing jobs, providing social benefits to the unemployed and facilitating job search.

Basic instruments of active and passive LMP are presented in the text as well as conditions and effectiveness of their application, and financing in the EU member states during economic crisis.

The analysis performed showed that the LMP introduced in different states differed greatly depending on the chosen LMP model. It can be stated that expenses for active and passive instrument increased in all member states during crisis. However, the level of changes differed among the states. The largest increase has been noted among old member states. The largest share of the expenses for LMP was spent on passive LMP. During economic downturn the number of beneficiaries of passive LMP increased.

The effectiveness of the instruments used is evaluated differently among the member states. Reliable analysis of LMP effectiveness during crisis requires more time and preparation of unified research methodology.

\section{Le fonctionnement et le financement de la politique du marché du travail européen au cours de la crise économique mondiale}

La politique du marché du travail est considérée comme un élément de l'intervention étatique dans les mécanismes du marché, qui résulte des effets indésirables survenant sur ce marché. La détérioration de la situation sur le marché du travail causée par la crise économique mondiale a conduit à une augmentation des tâches de la politique du marché du travail (LMP) visant à protéger les emplois existants, assurer la protection sociale des chômeurs et soutenir leur insertion professionnelle.

Larticle présente les principaux instruments de politiques active et passive du marché du travail ainsi que la spécificité et l'efficacité de leur application et leur financement dans la crise économique dans l'UE. Lanalyse effectuée montre que 
la politique du marché du travail mise en œuvre dans les différents pays varie considérablement, selon le modèle de cette politique. On observe que les dépenses sur les instruments actifs et passifs on augmenté dans tous les Etats membres de l'UE au cours de la crise. Cependant, le niveau des changements diffère entre les pays. La plus forte augmentation des dépenses au cours de la période analysée a été enregistrée dans les anciens Etats membres. La plus grande part des moyens pour LMP a été destinée à la politique passive. Au cours du ralentissement économique le nombre de bénéficiaires des instruments passifs a considérablement augmenté.

Leefficacité des instruments est évaluée différemment dans les États membres. Une analyse approfondie de l'efficacité de la politique du marché du travail en période de crise exige plus de temps et une méthodologie unifiée. 